\title{
Soils of Archeological Landscape Sorokino 1 (Orel Oblast): Reconstruction of Natural Changes and Anthropogenic Transformation of the Environment
}

\author{
Yu. G. Chendev ${ }^{a, *}$, A. A. Golyeva ${ }^{b}$, A. V. Dolgikh ${ }^{b}$, S. V. Uvarkin ${ }^{c}$, A. N. Golotvin ${ }^{d}$, V. G. Belevantsev ${ }^{a}$, \\ V. A. Sarapulkin ${ }^{a}$, and D. I. Dudin ${ }^{a}$ \\ ${ }^{a}$ Belgorod National Research University, Belgorod, 308015 Russia \\ ${ }^{b}$ Institute of Geography, Russian Academy of Sciences, Moscow, 119017 Russia \\ ${ }^{c}$ Research and Production Association "Chernozem'e”, Lipetsk, 398024 Russia \\ ${ }^{d}$ Archeological Park Argamach, Argamach-Pal'na, Eletsk district, Lipetsk oblast, 399758 Russia \\ *e-mail: Chendev@bsu.edu.ru \\ Received July 5, 2018; revised October 23, 2018; accepted November 28, 2018
}

\begin{abstract}
Soil-archeological studies were performed in the area of the ancient Russian settlement Sorokino 1 dating back to the 13th century AD and located in the upper reaches of the Orlik River (Khotynets district, Orel oblast) within the natural zone of deciduous forests. Morphological, physical, and chemical properties of soils associated with the archeological monument and with the background area under the forest were analyzed. Phytolith spectra and the radiocarbon age of soil organic matter were determined in the paleosols of the archeological monument and in the background surface soils. A comparative analysis of the soil features-indicators of the environment-allowed us to determine and characterize the main stages of the formation of soils and landscapes under the influence of climate changes and anthropogenic factors. Climate-related alternation of the phases of steppe and forest development in the study area was revealed. Steppe conditions in the Boreal period of the Holocene were replaced by the spreading of deciduous forests in the Holocene Optimum (Middle Atlantic period). At the end of the Atlantic period, steppe landscapes reappeared in the area, which was reflected in the intensification of the activity of steppe burrowers (mole rats) in the soil profiles. Steppe formation in river valleys during the Medieval Climatic Optimum was replaced by the propagation of forests in the subsequent Little Ice Age. The analysis of phytolith complexes of different ages indicated that the forests growing in the studied area in the Late Holocene included both deciduous and coniferous trees and reflected cooler climatic conditions in comparison with the deciduous forests without conifers of the Atlantic Optimum. In the recent centuries of the active agricultural development, forests have been replaced by arable land and hayfields, which has led to the formation of chernozems in the areas previously occupied by dark gray forest soils (Luvic Greyzemic Phaeozems).
\end{abstract}

Keywords: Central Russian Upland, ancient Russian settlements, paleosols, anthropogenic evolution of soils, Chernozems, Phaeozems, Luvisols

DOI: $10.1134 / \mathrm{S} 106422931906005 \mathrm{X}$

\section{INTRODUCTION}

For many years, interdisciplinary soil-archaeological studies have been performed on the territory of the East European Plain. Their results at each new studied site expand the range of ideas about the historical stages of the economic development of the territory and regional features of the natural development of soils and landscapes in the Holocene. One of the longstudied regions is the Central Russian Upland [1, 2, 15]. In this area, soil and archaeological investigations have been performed in all natural zones-from the zone of deciduous forests to the steppe zone, but not uniformly everywhere. The least studied part of this area is the northern forest-steppe and the zone of deciduous forests.

In May 2017, in the zone of reconstruction of the Druzhba Oil Pipeline in Khotynets district of Orel oblast, employees of the Chernozemye Scientific and Production Association under the supervision of S.V. Uvarkin conducted archaeological excavations in the area of the ancient Russian settlement Sorokino 1; soil geographers also took part in this work. The study area corresponds to the southern part of the zone of deciduous forests near the boundary with the forest-steppe zone.

The aim of our study to trace the historical stages of the formation of the evolution of soils and the environ- 

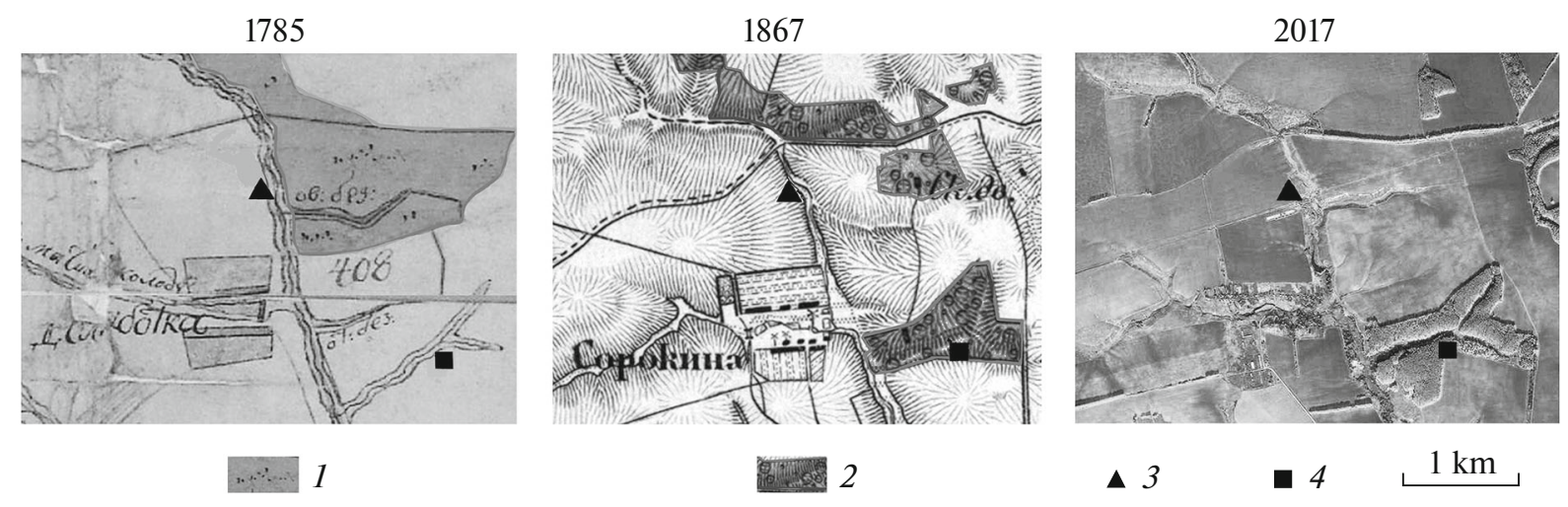

Fig. 1. A scheme of soil-archaeological investigations at Sorokino 1 key site and its environment in different historical periods. Forests on the maps of (1) 1785 and (2) 1867; (3) location of the soil-archaeological site; and (4) location of the studied background soils under forest.

ment under the impact of natural and anthropogenic factors in the area of Sorokino 1 key site.

\section{OBJECTS AND METHODS}

The study area is located $40 \mathrm{~km}$ northwest of Orel, within the interfluve and valley of the Orlik River in its upper reaches ( $2 \mathrm{~km}$ south of its source). The nearest settlement-the village of Sorokino-is found $1 \mathrm{~km}$ south of the excavation site.

In the study area, two zonal soil subtypes are most common: gray and dark gray forest soils [10] (Haplic Luvisols (Loamic, Humic) and Luvic Greyzemic Phaeozems (Loamic), respectively [20]). This indicates that prior to the beginning of the modern economic development of the territory about 300400 years ago [13], local landscapes were represented by deciduous forests. This is important in the context of paleoenvironmental reconstructions performed for the studied archeological site.

To restore the natural appearance of vegetation in the study area, a historical-cartographic study was carried out using an analysis of large-scale historical cartographic sources and a high-resolution satellite image of the modern period. We used the plan of Bolkhovsky district of Oryol governorship on a scale of $1: 42000$ dated back to 1785 (the period of the general land survey of the Russian Empire) [11] and a fragment of the Military Topographic Map of the Orel province of 1867 on a scale of $1: 126000$ [5]. Satellite information obtained from the web source ArcGISWorldImagery (https:// www.arcgis.com/home/webscene/viewer.html) characterized the modern situation.

Land uses in the area of the archaeological site in 1785, 1867, and 2017 are depicted in Fig. 1. According to the presented scheme, a significant segment of the eastern part of the Orlik River valley from the outer edge of the floodplain to the local divide was covered by forests at the end of the 18th century. However, the western part of the river valley and the adjacent water- shed were used for cropland 230 years ago. According to the map of 1867, certain changes occurred in the forest cover of the study area. The territory covered with forests near the archeological site noticeably decreased, whereas the part of the land to the east of the Orlik River was still characterized by an islandtype distribution of forest groves. The analysis of the maps of 1785 and 1867 demonstrates that forests closely approached the floodplain part of the Orlik River in places without significant transformation by the agricultural activities. Thus, we can assume that almost the entire territory shown in Fig. 1 was under forest vegetation in the period before the agricultural development of this land (before the 17th century). It is probable that river floodplains were also under forest vegetation, though these floodplains are characterized by numerous places of the discharge of springs and are often swampy. In particular, the Orlik River floodplain in the investigated area was covered by forests.

In some places of the study area, a characteristic feature in the history of its economic development was the use of areas freed from forest for agricultural land with further abandonment of the land, which was again overgrown with forests. This is seen from Fig. 1, where the dynamics (disappearance-appearance) of forest groves can be traced at two sites.

One of these areas (the only forest fragment preserved in the modern period) was used as the background site to study the features of pedogenesis under forest vegetation. On the map of 1785, it is depicted as an arable land. On the map of 1867, it was under a forest, which is still growing today. Thus, the period of continuous existence of the forest at this site is at least 150 years. The duration of the previous stage of arable land was probably relatively short (first decades). The features of former plowing could not be identified in the soil profiles examined at this site. Thus, we suppose that the period of the development under forest vegetation for more than 150 years is sufficient for an 
almost complete restoration of characteristics features of forest soils.

In addition to the background soils, we also studied the main objects of study were the soils formed in the area of the archeological site. Six soil pits were examined on different elements of the local topography: from a gentle watershed slope to the floodplain of the Orlik River. Additionally, we studied the features of pedogenesis associated with the functioning of the ancient settlement and with the buried hollow stretching down the valley slope from the ancient settlement in its upper end to the floodplain. In the bottom of this hollow, buried soils were examined; we also analyzed the soils developing from the material filling the hollow.

The objects of archaeological research were the cultural layers of the settlement; they contain artifacts that are used for archeological dating and for identifying various ethno-cultural features of the functioning of this historical monument. The area of archaeological excavations at the settlement of Sorokino 1 exceeds 20 ha. According to the artifacts, this settlement was founded in the first half of the 13th century. According to pottery fragments, the most probable period of its active functioning was from 1200 to $1240 \mathrm{AD}$. The end of its existence, according to archaeologists, was associated with the raid of the Mongol-Tatars. This is evidenced by traces of fire in wooden structures of dwellings in the settlement and by the discovered treasure of agricultural items hidden in an unfinished pit for storing grain.

A set of diverse methods were applied in the study: morphological analysis of soil profiles, comparative geographic method, archaeological dating by artifacts, radiocarbon dating of soil organic matter, phytolith analysis, determination of the bulk density of the soil, potentiometric determination of the $\mathrm{pH}$ of soil suspension, and determination of the content of the $\mathrm{CO}_{2}$ of carbonates (acidimetric method) and the organic carbon content by wet combustion (Tyurin's method). The cultural layer of the settlement was dated by the archeological methods. Radiocarbon dates were obtained for the humus of the soils of different ages and for the material filling the tunnels of burrowing animals (mole rats). The radiocarbon dating was performed in the Radiocarbon Laboratory of the Institute of Environmental Geochemistry of the National Academy of Sciences of Ukraine (Kiev, Ukraine) using the liquid scintillation counting method [22]. The ${ }^{14} \mathrm{C}$ isotope content was measured on a Quantulys 1220T ultra low-level liquid scintillation spectrometer. Calibration of radiocarbon dates was performed in the Radiocarbon Laboratory of the Institute of Geography of the Russian Academy of Sciences (Moscow) using OxCal v4.2.4 calibration program [19] based on the IntCal 13 calibration curve [21]. Phytolith analysis was performed at the Institute of Geography of the Russian Academy of Sciences using the standard method [7].

\section{RESULTS AND DISCUSSION}

The background soils under the natural forest were studied in the upper part of the watershed slope passing into the slope of the local balka (ravine) to the east of the village of Sorokino, about $3 \mathrm{~km}$ southeast of the archaeological site. The slope of $1.5^{\circ}-2^{\circ}$ was covered by a monodominant birch forest with mature trees of $30-35 \mathrm{~m}$ in height and up to $40 \mathrm{~cm}$ in diameter. The average distance between the trees was $7-8 \mathrm{~m}$; the canopy density was about $60-70 \%$. Mountain ash and buckthorn were found in the undergrowth. About $15 \%$ of the soil surface was covered with herbs, including starwort (Stellaria sp.), strawberries (Fragaria sp.), goutweed (Aegopodium poagraria), Solomon's seal (Poligonatum sp.), lily-of-the-valley (Convallaria majalis), and wood bluegrass (Poa nemoralis). The soils studied in the pits were identified as silt loamy dark gray forest soils developing from silt loamy calcareous loesslike loam (Luvic Retic Greyzemic Phaeozems (Loamic) [20]).

The average morphometric characteristics of the studied background soils (according to the description of four soil profiles) are as follows: A1 $(0-20 \mathrm{~cm})-$ A1A2 (20-39 cm)-A1A2B (39-49 cm)-A2Bt (49$70 \mathrm{~cm})-\mathrm{Bt}(70-98 \mathrm{~cm})-\mathrm{BtC}(98-137 \mathrm{~cm})-\mathrm{Cca}$ $(137-180 \mathrm{~cm})$. The effervescence starts from $128 \mathrm{~cm}$.

The features of these soils attest to their long-term development under the forest canopy ; they have clear features of the textural differentiation in the form of bleached eluvial part of the somewhat coarser texture and the underlying dark-colored illuvial part with brown coatings on ped faces and heavier texture (Bt horizons).

At the same time, the presence of the tunnels of mole rats with somewhat blurred boundaries attests to the former stage (or stages) of steppe pedogenesis that could take place in the past, under more arid climatic conditions of the Holocene. The existence of such stage(s) was earlier demonstrated by paleosol studies in the northern part of the Central Russian Upland and in the southern taiga subzone [1,3]. Data on the radiocarbon age of humus from the fine earth material filling these tunnels as probable relics of the stage of dark-humus (chernozemic) pedogenesis are given in Table 1.

The phytolith analysis of this material from pit 3 (for which the radiocarbon dates were obtained) demonstrated the virtual absence of microbiomorphs in it. Thus, the material filling the tunnels was formed from phytolith-free soil layers that filled the tunnels. According to Golyeva [7], the information value of soil layers saturated with phytoliths, as a rule, spreads to a depth of $40 \mathrm{~cm}$ from the soil surface. At the same time, the presence of the gray-colored humified material in the paleotunnels suggests that this material was derived from the humified part of the paleosol profiles. Thus, we can suppose that the humus layer of the paleosols had an increased thickness $(>40 \mathrm{~cm})$ and 
Table 1. Radiocarbon age of humus in the material filling mole-rat tunnels in the soil profiles of Sorokino 1 key site

\begin{tabular}{|c|c|c|c|c|c|c|}
\hline \multirow[b]{2}{*}{ Sample } & \multirow[b]{2}{*}{$\begin{array}{c}\text { Laboratory } \\
\text { no. }\end{array}$} & \multicolumn{5}{|c|}{ Radiocarbon $\left({ }^{14} \mathrm{C}\right)$ age } \\
\hline & & $\begin{array}{c}\text { noncalibrated, } \\
\mathrm{BPH}^{*}\end{array}$ & $\begin{array}{c}\text { calibrated } \\
(1 \sigma, 68.2 \%)^{* *}\end{array}$ & $\begin{array}{c}\text { calibrated } \\
(2 \sigma, 95.2 \%)^{* *}\end{array}$ & $\begin{array}{c}\text { cal BP, } \\
\text { mean }(\mu) \pm \\
\operatorname{sigma}(\sigma)\end{array}$ & $\begin{array}{c}\operatorname{median}(m), \\
\text { cal BP }\end{array}$ \\
\hline Background; pit 3, 80-90 cm & Ki-19388 & $4220 \pm 160$ & $4970-4523$ & $5301-4357$ & $4775 \pm 234$ & 4757 \\
\hline Background; pit3, $150-155 \mathrm{~cm}$ & Ki-19389 & $10900 \pm 150$ & $12959-12699$ & $13080-12576$ & $12829 \pm 133$ & 12819 \\
\hline BS, pit $10,85-98 \mathrm{~cm}$ & Ki-19381 & $7460 \pm 180$ & $8417-8050$ & $8630-7934$ & $8272 \pm 181$ & 8268 \\
\hline BS, pit $10,95-105 \mathrm{~cm}$ & Ki-19382 & $7700 \pm 180$ & $8950-8389$ & $9075-8196$ & $8645 \pm 221$ & 8618 \\
\hline $\mathrm{BS}$, pit $10,80-90 \mathrm{~cm}$ & Ki-19383 & $6680 \pm 120$ & $7655-7461$ & $7786-7329$ & $7557 \pm 101$ & 7554 \\
\hline $\mathrm{BS}$, pit $10,100-110 \mathrm{~cm}$ & Ki-19384 & $7260 \pm 150$ & $8288-7940$ & $8381-7796$ & $8092 \pm 147$ & 8091 \\
\hline
\end{tabular}

BS, buried soil at the bttom of the paleohollow. * Radiocarbon dates are given in years before 1950 (BP-before present). ** Calibrated ages are also given in years before 1950 (cal BP). At $1 \sigma$, the probability is $68.2 \%$; at $2 \sigma, 95.4 \%$.

Table 2. Distribution of siliceous microbiomorphs and groups of phytoliths in the soil samples from Sorokinno 1 key site, $\%$

\begin{tabular}{|c|c|c|c|c|c|c|c|c|c|c|c|}
\hline \multirow{2}{*}{ Sample } & Total & Spicules & Phytoliths & \multirow{2}{*}{1} & \multirow{2}{*}{2} & \multirow{2}{*}{3} & \multirow{2}{*}{4} & \multirow{2}{*}{5} & \multirow{2}{*}{6} & \multirow{2}{*}{7} & \multirow{2}{*}{8} \\
\hline & \multicolumn{3}{|c|}{ species $/ \%$} & & & & & & & & \\
\hline Background; pit3, A1, 0-20 cm & $201 / 100$ & - & $201 / 100$ & 57 & 9 & 8 & 20 & 4 & 1 & - & 1 \\
\hline $\mathrm{BS}$, pit $10 .\left[\mathrm{A} 1^{\mathrm{I}}\right], 0-5 \mathrm{~cm}$ & $390 / 100$ & - & $390 / 100$ & 58 & 8 & 11 & 18 & 2 & - & 3 & - \\
\hline $\mathrm{BS}$, pit $10 .\left[\mathrm{A} 1^{\mathrm{II}}\right], 15-24 \mathrm{~cm}$ & $96 / 100$ & - & $96 / 100$ & 57 & 6 & 12 & 17 & 6 & - & - & 2 \\
\hline BS, pit 10 , mole tunnel, $80-90 \mathrm{~cm}$ & $22 / 100$ & $1 / 5$ & $21 / 95$ & 76 & - & 14 & 10 & - & - & - & - \\
\hline
\end{tabular}

Vegetation cenoses: (1) dicotyledonous herbs, (2) conifers, (3) forest grasses, (4) meadow grasses, (5) steppe grasses, (6) weeds, (7) reed grass, and $(8)$ sedges.

that the tunnels of mole rats were filled with the material from the deep part of the humus horizon.

According to the phytolith spectrum from the A1 horizon of the background dark gray forest soil ( $0-$ $20 \mathrm{~cm}$ ), the composition of the microbiomorph complex is typical of the upper part of the humus soil horizons (Table 2). The phytolith complex is diverse and is characterized by a predominance of phytoliths of meadow herbs with elements of steppe flora and weedy vegetation. There are also phytoliths of conifers and phytoliths of forest grasses. Many phytoliths are charred. In general, the phytolith analysis of the humus horizon of the background soil under forest attests to the good cover of herbs with elements of ruderal flora developing under a mixed type of woodland. The spectrum of phytoliths is characterized by a mixed composition with participation of meadow-steppe herbs, weeds, and forest vegetation and can be considered a reflection of the complicated history of the landscape subjected to a break in its development under forest during the period of active agricultural development of this territory in the 18th century. The discrepancy between the results of the phytolith analysis (attesting to the good cover of herbs under the forest canopy) and the real situation (modern herbs cover no more than $15 \%$ of the surface) is also an argument in favor of the complicated history of the formation of the phytolith complex of this soil with alternation of the periods with dense and sparse cover of herbs. We argue that the phytolith complex of the upper $20-\mathrm{cm}-$ thick soil layer reflects the landscape history in the past $300-500$ years.

The main soil studies of the archeological site were performed in the northern part of the archeological excavation and on the adjacent territory. We examined a catena from the local divide to the floodplain of the Orlik River (Fig. 2) and the buried soils in the paleohollow on the valley slope (Fig. 3).

The uppermost pit 5 was studied on a gentle $\left(1.5^{\circ}-2^{\circ}\right)$ slope in the northwestern part of the archeological excavation under a cropland with winter wheat. This soil profile was significantly altered by centuries-old agricultural activity (judging from the plan of 1785, the studied site had been already used for crop cultivation by that time, i.e., the period of its continuous agricultural development is more than 230 years). The soil profile had the following horizonation: Ap $(0-29 \mathrm{~cm})-$ A1B $(29-43 \mathrm{~cm})-B A 1(43-63 \mathrm{~cm})-B 1 \mathrm{t}(63-97 \mathrm{~cm})-$ B2t $(97-118 \mathrm{~cm})-\mathrm{BtCg}(118-146 \mathrm{~cm})-\mathrm{Cg}(146-$ $180 \mathrm{~cm})$. The soil did not contain carbonates in the entire profile $(180 \mathrm{~cm})$. It was diagnosed as a silt loamy podzolized chernozem with gleyic features in the deep horizons (ground-gleyed soil) developing from the 
heavy loesslike loam (Luvic Greyzemic Chernic Phaeozem (Loamic, Aric) [20]).

Podzolization features are manifested by whitish skeletans in the B1t and B2t horizons and, in some loci, even deeper (down to the $\mathrm{BtCg}$ horizon). It is probable that the initial soil (before its agricultural development) represented a gray forest soil (Haplic Luvisol [20]) formed under the canopy of broadleaved forest. However, the long-term economic development of the territory, including the ancient Russian period of the existence of the settlement and the agricultural use of soils in the recent centuries, contributed to darkening of gray forest soils and their transformation into chernozems (Chernozems [20]). The transformation (progradation) of gray forest soils into chernozems upon the long-term plowing in the foreststeppe zone has been considered in previous publications [16, 17]. This process manifests itself in the increased content of organic matter in the entire profile of the cultivated soil (pit 5) in comparison with the background soil under forest (pit 3) (Table 3). The accumulation of humus takes place upon the longterm $(>100$ years) soil cultivation in the extensive farming systems with low rates of the applied organic fertilizers [15-17]. The studied area near Sorokino 1 archeological site confirms previous conclusions.

The second studied soil (pit 11) was found on a gentle $\left(3^{\circ}\right)$ slope of the Orlik River valley in the northeastern part of the archeological excavation. This area was at the periphery of the ancient Russian settlement.

The soil profile does not contain morphologically distinct features of the anthropogenic influences in the past and at present (except for indirect impact of forest cutting and transformation of the former forest plot into hayfield). This soil has been developing under the hayfield for more than 230 years. The forbgrassy vegetation includes wheat grass, meadow grass, sage, euphorbia, bedstraw, field strawberry, dandelion, yarrow, etc.

The soil examined in pit 11 has the following horizonation: Sod mat $(+3-0 \mathrm{~cm})-\mathrm{A} 1(0-45 \mathrm{~cm})-\mathrm{A} 1 \mathrm{~B}$ $(45-62 \mathrm{~cm})-\mathrm{B}(62-80 \mathrm{~cm})-\mathrm{BC}(80-95 \mathrm{~cm})-$ BCca $(95-155 \mathrm{~cm})$. Carbonates in the form of pseudomycelium appear from the depth of $90 \mathrm{~cm}$. The soil profile is considerably disturbed by burrowing steppe animals (mole rats). The features of podzolization are absent, and this soil can be classified as a leached chernozem (Luvic Chernozem (Loamic, Pachic) [20]). Taking into account the initial analogy of this soil with the dark gray forest under the forest (pit 3) and the results of analyses, we argue that the long-term soil functioning under the regularly mown hayfield is accompanied by the transformation of the former gray forest soil into chernozem with an increase in the thickness of the humus horizon and humus content and some accumulation of carbonates.

Within the same hayfield, somewhat lower down the slope, on its steeper part $\left(4^{\circ}-8^{\circ}\right)$, the profiles of

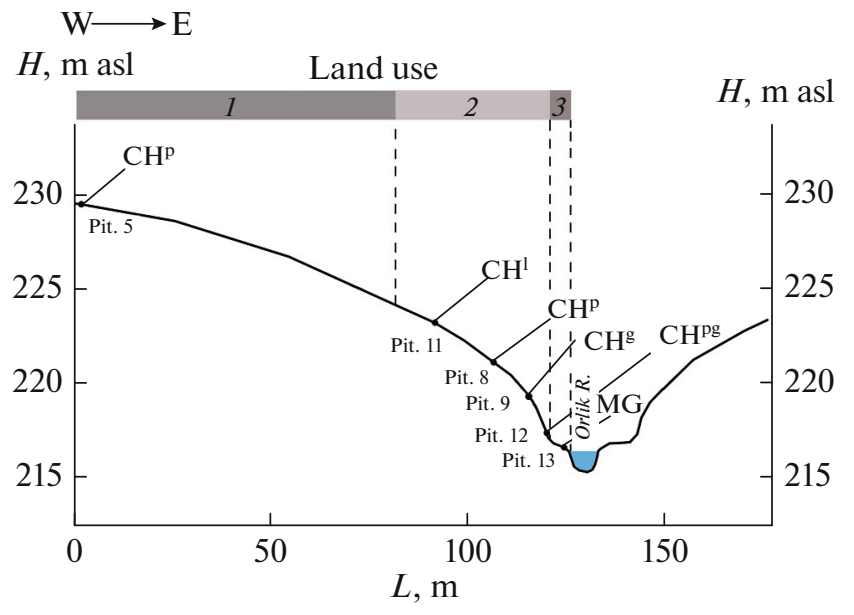

Fig. 2. Hypsometric profile across the interfluve slope and the Orlik River valley with indication of studied soil pits and classification position of the soils: $\mathrm{CH}^{\mathrm{p}}$-podzolized chernozem, $\mathrm{CH}^{\mathrm{pg}}$-podzolized deeply gleyed chernozem, $\mathrm{CH}^{1}$-leached chernozem, and $\mathrm{MG}-$ meadow-gley soil. Land use: (1) cropland, (2) hayfield, and (3) floodplain wet meadow.

podzolized chernozems (Luvic Greyzemic Chernic Phaeozems (Loamic, Pachic)) were studied in three pits. In these soils, whitish skeletans could be seen down to the BC horizon. The soils did not contain carbonates in the entire profile (over $150 \mathrm{~cm}$ ). The features of podzolization in these soils attest to their development under forest vegetation in the past. However, the Bt horizon (as in pit 5) is not developed, which may be indicative of a shorter period of the soil development under forest canopy. The humus layer has an increased thickness $(\mathrm{A} 1+\mathrm{A} 1 \mathrm{~B}, 50-60 \mathrm{~cm})$; the soils contain numerous tunnels left by mole rats, which may be indicative of the long period of the soil development under herbaceous (meadow-steppe) vegetation. We suppose that the periods of steppe pedogenesis on the slopes of the Orlik River valley alternated with the periods of forest pedogenesis. However, the integral effect of the chernozem-forming process under meadow-steppe vegetation is stronger that the effect of the forest pedogenesis.

This assumption is confirmed by the results of our study the soils in the bottom of a buried hollow on the valley slope not far from the earlier described pits 11 and 5. This paleohollow (one of several paleohollows identified within the ancient settlement) has a width of $14-15 \mathrm{~m}$ and a depth of about $1 \mathrm{~m}$ in the central part. Small fragments of ancient Russian pottery are found everywhere in the humified material filling the paleohollow. Thus, it may be concluded that the natural hollow was gradually filled with fine earth transported along its slopes and bottom, which resulted in an artificial leveling of the surface during the settlement's 


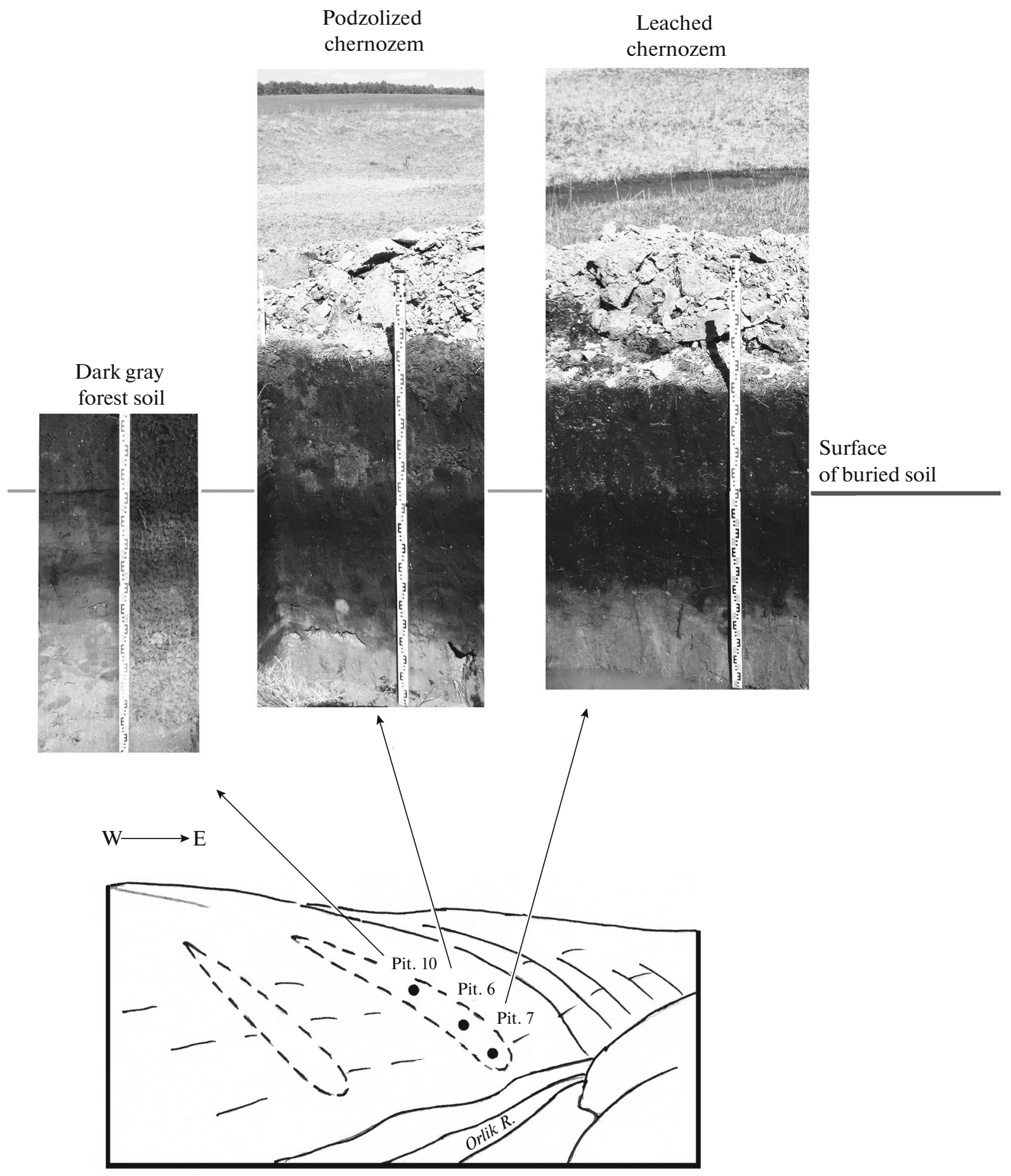

Fig. 3. Soil pits studied in the paleohollow and morphology of the soils buried under fine earth material during the existence of the ancient Russian settlement.

functioning. The morphology of the soils studied in different parts of the hollow bottom is shown in Fig. 3 .

The absolute height of the surface at the highest point (pit 10) is $223.5 \mathrm{~m}$. This is the upper part of the slope towards the Orlik River, not far from pit 11, $35 \mathrm{~m}$ upslope from the river floodplain and $40 \mathrm{~m}$ from the river bank (the absolute height of the water level in the river at the time of the research was $216.8 \mathrm{~m}$ ). In the area of pit 10 , the slope steepness is $3^{\circ}$. The description of the soil developed from the material filling the paleohollow is given below.

A1', 0-12 cm. Gray to dark gray, slightly dry, crumb-granular silt loam; compacted; with many roots and earthworm paths; slightly wavy boundary. 
Table 3. Some physical, physicochemical, and chemical properties of studied soils

\begin{tabular}{|c|c|c|c|c|c|c|c|}
\hline \multirow{2}{*}{ Pit } & \multirow{2}{*}{ Depth, cm } & \multirow{2}{*}{$\begin{array}{c}\text { Hygroscopic } \\
\text { water, } \%\end{array}$} & \multicolumn{2}{|c|}{$\mathrm{pH}$} & $\mathrm{CO}_{2 \text { carb }}$ & $\mathrm{C}_{\text {org }}$ & Humus \\
\hline & & & $\mathrm{H}_{2} \mathrm{O}$ & $\mathrm{KCl}$ & & $\%$ & \\
\hline \multirow[t]{7}{*}{ Background soil, pit 3} & $0-20$ & 2.60 & 6.31 & 5.33 & 0 & 1.87 & 3.22 \\
\hline & $20-35$ & 2.90 & 6.05 & 4.47 & 0 & 0.87 & 1.50 \\
\hline & $35-50$ & 3.37 & 6.17 & 4.20 & 0 & 0.46 & 0.79 \\
\hline & $50-74$ & 3.33 & 6.16 & 4.04 & 0 & 0.16 & 0.28 \\
\hline & $74-114$ & 3.59 & 5.78 & 4.23 & 0 & 0.10 & 0.18 \\
\hline & $114-144$ & 3.24 & 6.75 & 6.42 & 3.36 & 0.18 & 0.31 \\
\hline & $144-180$ & 3.06 & 8.34 & 7.34 & 8.25 & 0.15 & 0.25 \\
\hline \multirow{7}{*}{$\begin{array}{l}\text { Modern arable analogue } \\
\text { of background soil, pit } 5\end{array}$} & $0-29$ & 3.27 & 6.33 & 5.26 & 0 & 2.69 & 4.64 \\
\hline & $29-43$ & 3.35 & 6.35 & 5.05 & 0 & 2.20 & 3.79 \\
\hline & $43-64$ & 3.10 & 6.13 & 4.85 & 0 & 2.11 & 3.63 \\
\hline & $64-96$ & 2.23 & 5.96 & 5.54 & 0 & 0.77 & 1.32 \\
\hline & $96-118$ & 3.10 & 5.90 & 4.03 & 0 & 0.32 & 0.56 \\
\hline & $118-146$ & 3.20 & 5.90 & 4.05 & 0 & 0.24 & 0.41 \\
\hline & $146-166$ & 3.17 & 6.09 & 4.10 & 0 & 0.16 & 0.28 \\
\hline \multirow{7}{*}{$\begin{array}{l}\text { Modern analogue of back- } \\
\text { ground soil under hayfield } \\
\text { (at the Orlik valley/interfuve } \\
\text { slope interface), pit } 11\end{array}$} & $0-22$ & 4.78 & 6.53 & 5.71 & 0 & 3.02 & 5.21 \\
\hline & $22-45$ & 4.12 & 6.68 & 5.43 & 0 & 1.98 & 3.41 \\
\hline & $45-60$ & 3.52 & 6.84 & 5.51 & 0 & 1.23 & 2.12 \\
\hline & $60-80$ & 3.71 & 6.98 & 5.57 & 0 & 1.06 & 1.82 \\
\hline & $80-95$ & 3.93 & 7.68 & 6.93 & 2.33 & 0.70 & 1.21 \\
\hline & $95-125$ & 2.76 & 8.41 & 7.36 & 10.80 & 0.55 & 0.94 \\
\hline & $125-155$ & 2.98 & 8.53 & 7.34 & 11.33 & 0.35 & 0.60 \\
\hline \multirow{4}{*}{$\begin{array}{l}\text { Soil develoepd in the material } \\
\text { filling the paleohollow, pit } 10\end{array}$} & $0-12$ & 4.06 & 6.31 & 5.44 & 0 & 3.42 & 5.89 \\
\hline & $12-23$ & 4.46 & 6.42 & 5.32 & 0 & 3.42 & 5.89 \\
\hline & $23-52$ & 4.21 & 6.08 & 4.74 & 0 & 3.19 & 5.50 \\
\hline & $52-87$ & 1.26 & 6.18 & 4.65 & 0 & 3.00 & 5.18 \\
\hline \multirow{8}{*}{$\begin{array}{l}\text { Buried soil at the bottom } \\
\text { of the paleohollow, pit } 10\end{array}$} & $0-15$ & 2.80 & 6.02 & 4.90 & 0 & 1.83 & 3.16 \\
\hline & $15-24$ & 2.16 & 6.03 & 4.67 & 0 & 1.10 & 1.89 \\
\hline & $24-40$ & 1.93 & 6.14 & 4.59 & 0 & 1.04 & 1.79 \\
\hline & $40-70$ & 2.00 & 6.13 & 4.42 & 0 & 0.60 & 1.03 \\
\hline & $70-85$ & 2.22 & 6.26 & 4.42 & 0 & 0.28 & 0.49 \\
\hline & $85-100$ & 2.30 & 6.33 & 4.41 & 0 & 0.20 & 0.34 \\
\hline & $100-123$ & 2.69 & 7.18 & 4.33 & 0 & 0.14 & 0.24 \\
\hline & $123-148$ & 3.06 & 6.36 & 4.31 & 0 & 0.10 & 0.18 \\
\hline
\end{tabular}

A1", 12-23 cm. Gray, slightly dry, crumb-granular silt loam; compacted; with few bleached grains of skeletans; abundant coprolites and earthworm paths; many fine roots; in the lower part, fragments of pottery of the ancient Russian period are present.

A1B, 23-52 cm. Dark gray with brownish tint; moist; crumb-angular-blocky, with elements of granular structure; silt loam; compacted; with bleached skeletans in some places; many coprolites and earth- worm paths; fine roots; few remains of the ancient Russian pottery.

A1C, 51-86 cm. Homogeneous brownish dark brown; angular blocky-crumb structure with the presence of very fine (powdery) and granular aggregates; silt loam; compacted; with many coprolites and earthworm paths; contains mole-rat tunnels filled with lighter-colored material; moderate amount of roots; few remains of the ancient Russian pottery. 
The soil developed in the material filling the paleohollow does not contain carbonates. It is weakly differentiated into genetic horizons and contains clear features of the soil transformation by mesofauna.

The contact with the buried soil is at the depth of 86 to $90 \mathrm{~cm}$. It is marked by a darker color and higher density of the buried soil. The buried soil profile consists of the following genetic horizons: [A1] $(0-15 \mathrm{~cm})-$ [A1A2] $(15-24 \mathrm{~cm})-[\mathrm{A} 1 \mathrm{~A} 2 \mathrm{~B}](24-40 \mathrm{~cm})-[\mathrm{A} 2 \mathrm{Bt}]$ $(40-70 \mathrm{~cm})-[\mathrm{Bt}](70-85 \mathrm{~cm})-[\mathrm{BtCg}](85-123 \mathrm{~cm})-$ [Cg] $(123-178 \mathrm{~cm})$. Whitish skeletans appear in the [A1A2] horizon in some loci; in the underlying [A1A2B] and [A2Bt] horizon, they are clearly seen on the walls of fissures. In the $[\mathrm{Bt}]$ and $[\mathrm{BtCg}]$ horizons, brown and light brown organomineral coatings cover angular blocky and prismatic aggregates. Gley features in the $[\mathrm{BtCg}]$ and $[\mathrm{Cg}]$ horizons are manifested by the bluish ting in some loci and by numerous iron-manganic concentrations. A characteristic feature of the buried soil is the presence of light gray, gray-brown, and yellowish-brown filled tunnels left by mole rats in its profile beginning from the $[\mathrm{A} 2 \mathrm{Bt}]$ horizon. These features of the faunal activity are old, as their boundaries are not very distinct. The buried soil does not contain carbonates in the entire profile.

It can be classified as a silt loamy dark gray forest soil with gleyic features in the lower horizons.

The second pit studied in the bottom of the paleohollow (pit 6) was excavated $20 \mathrm{~m}$ to the east of pit 10 (closer to the river) at the absolute height of $221.5 \mathrm{~m}$. The slope steepness is $4^{\circ}-5^{\circ}$. In this soil pit, the upper humified layer filling the paleohollow contains fragments of the ancient Russian pottery. At the depth of $65 \mathrm{~cm}$, the upper boundary of the buried soil (chernozem) is found. This soil has the following horizonation: [A1] $(0-25 \mathrm{~cm})-[\mathrm{A} 1 \mathrm{~B}](25-40 \mathrm{~cm})-[\mathrm{BA} 1]$ $(40-57 \mathrm{~cm})-[\mathrm{B}](57-82 \mathrm{~cm})-[\mathrm{BC}](82-112 \mathrm{~cm}$ and deeper). It does not contain carbonates. On the dried wall of pit, whitish bleached skeletans appear in the soil from the depth of $40 \mathrm{~cm}$. In the [B] and [BC] horizons, the skeletans are seen along the vertical fissures attesting to the development of lessivage in the buried soil under the forest vegetation.

According to its morphological features, the buried paleosol can be classified as a thin slightly eroded podzolized chernozem. This soil is considerably transformed by the burrowing activity of animals. The tunnels left by more rats cross the zones enriched in skeletans; evidently, they were formed after the formation of the skeletans, under conditions of meadow-steppe pedogenesis that replaced the earlier stage of forest pedogenesis.

Pit 7 was examined closer to the floodplain, in the lower part of the paleohollow bottom, $10 \mathrm{~m}$ downslope from pit 6 , on the slope of $6^{\circ}-7^{\circ}$. In this pit, the humified fine earth material with pottery fragments was well structured by earthworms and also had a thickness of $65 \mathrm{~cm}$. The paleosol buried under it had the follow- ing horizonation: [A1] $(0-30 \mathrm{~cm})-[\mathrm{A} 1 \mathrm{~B}](30-40 \mathrm{~cm})-$ [B] $(40-58 \mathrm{~cm})-[\mathrm{BCg}](58-100 \mathrm{~cm}$ and deeper). The effervescence was absent; whitish skeletans were also absent in this paleosol. Filled tunnels left by mole rats were numerous. This soil was identified as a moderately eroded thin leached chernozem developing from the carbonate-free heavy covering loam. The meadowsteppe genesis of the paleosol studied in pit 7 is beyond doubt. This soil profile confirms our assumption about the steppe character of the slope of the Orlik River valley in its lower part in the first half of the 13th century (when the ancient settlement appeared in this area).

The analysis of three soil profiles in different parts of the bottom of the paleohollow allows us to suppose that, before the appearance of the ancient settlement, the boundary between the forest and meadow-steppe vegetation communities was found somewhere between pits 7 and 10, i.e., $30 \mathrm{~m}$ upslope from the floodplain and $35 \mathrm{~m}$ from the river channel. The western and eastern slopes of the Orlik River valley are close in their morphology. Thus, we can estimate the width of the steppe corridor between the forest-covered slopes of the valley and adjacent interfluves in the period of foundation of the ancient Russian settlement. According to our estimates, it was about $70 \mathrm{~m}$, including the floodplain.

In our opinion, the climate-driven steppization of the river valleys in the forest zone of the East European Plain during the little climatic optimum of the Holocene opened possibility for the development of new territories previously completely occupied by forests. Thus, new settlements appeared in the forest-steppe zone near the rivers.

The results of the morphological analysis of the soil profiles can be complemented by data on the phytolithic complex of the paleosol described in pit 10 .

[A1], $0-5 \mathrm{~cm}$. The sample contains many phytoliths. Meadow forms prevail, but there are particles characteristic of conifers and forest and steppe herbs (Fig. 4). In general, the vegetation was close to that described for pit 3. However, this sample does not contain phytoliths of weeds; at the same time, it contains phytoliths of reed. A combination of a large number of phytoliths with the presence of phytoliths characteristic of tall herbs possible in two cases: (a) a subordinate position in the relief, when fine earth (together with phytoliths) is transported from the higher positions, and the shallow groundwater table provides for the development of hydrophilic flora and (b) the artificial introduction of plant material by humans, which may be indicative of the cultural layer of the ancient settlement.

[A1A2], 15-24 cm. The number of phytoliths is significantly smaller, though it remains typical of the upper soil horizons. There is no reed in the composition of the phytolith complex. It is probable that this phytolith complex reflects one of the natural stages of the development of the landscape under the canopy of 

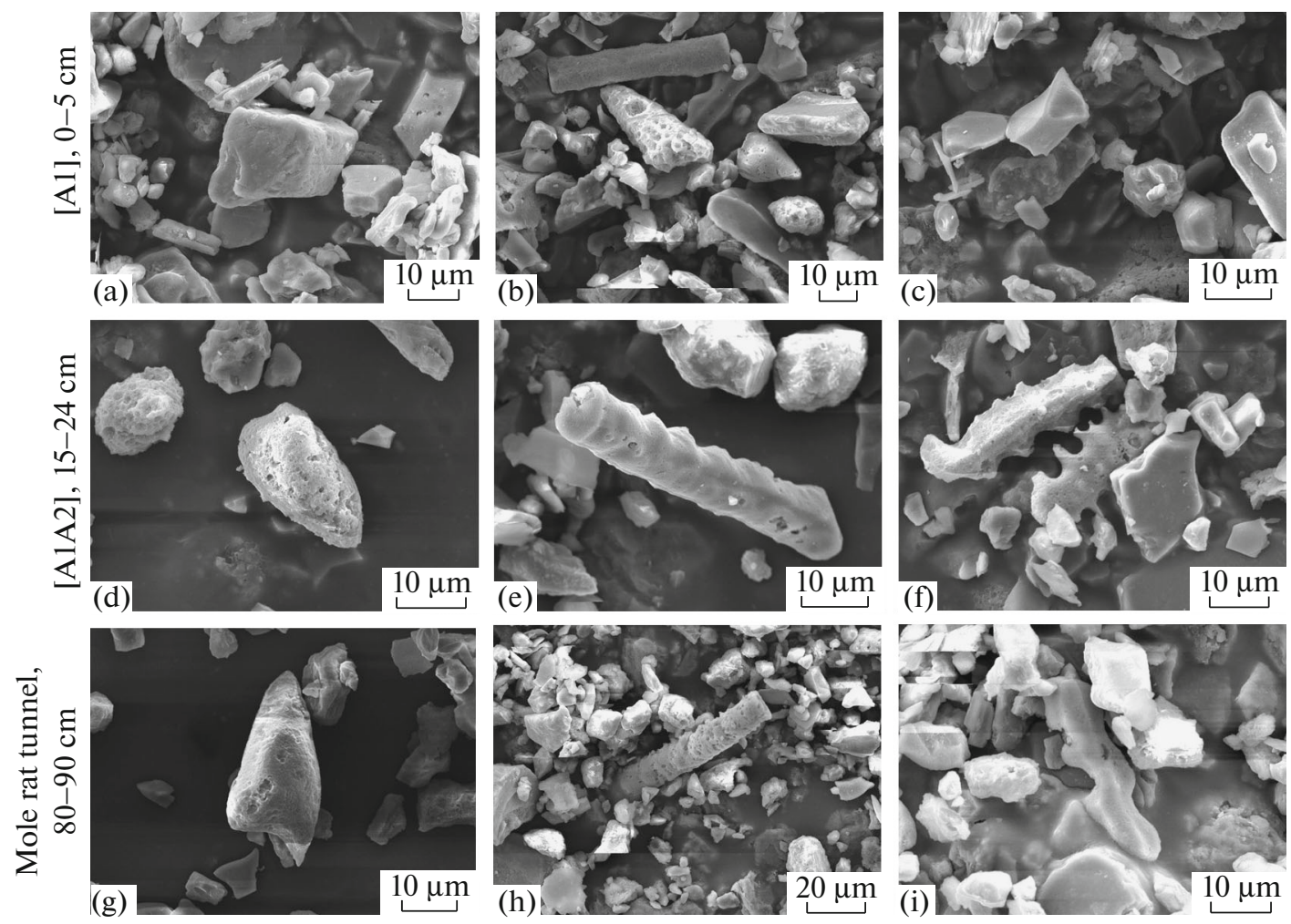

Fig. 4. Photos of phytoliths studied in the buried soil at the bottom of the paleohollow in the northeastern periphery of the ancient Russian settlement Sorokino 1. Phytoliths of (a) conifers, (b) mixture and forest (corroded grains) and meadow plants, (c) meadow and steppe grasses, (d) forest herbs, (e) meadow herbs, (f) cultivated cereals, (g) forest herbs, (h) dicots, and (i) meadow herbs.

sparse mixed forest with a well-developed grassy cover, or about the presence of large glides with meadow and steppe vegetation within the forest. At the same time, phytoliths of weeds and cultivated cereals are present, albeit in small numbers, which testifies to the artificial input of the remains of crops into the soil, i.e., to the development of agriculture in this area.

Thus, the results of the phytolith analysis confirm the boundary position of this site (pit 10) between the forest that occupied upward positions on the slope and the meadow-steppe vegetation down the slope.

In the buried soil of pit 10, radiocarbon dating of humus was performed for the samples taken from different depths and for the samples of the material filling the tunnels of more rats. These samples were also subjected to the phytolith analysis. The tunnels of mole rats had diffuse boundaries attesting to their old age. Many of them were filled with gray-colored humified material. The photos of these tunnels are shown in Fig. 5. Overall, four tunnels were studied; three of them (nos. 2, 3, 4, Fig. 5) were in approximately the same place; the fourth tunnel was found $1.5 \mathrm{~m}$ away (no. 1, Fig. 5). These tunnels were confined to the illuvial [B1t] and [B2t] horizons at the depths of 80$110 \mathrm{~cm}$. Data on the radiocarbon age of humus in the filling of the tunnels are presented in Table 1. The darkest material (no. 3, Fig. 5) was the only kind of the filling, in which phytoliths were present. Their composition attests to the soil development under the broadleaved forest with a well-developed herbaceous cover. The presence of sponge spicules indicates the proximity of the river. The composition of the phytolith complex from this tunnel differs from the composition of phytolith complexes in the other studied samples. In particular, the number of phytoliths of forest grasses in it is greater than the number of phytoliths of meadow grasses (pit 3). Thus, we can supposed that this soil developed under the broadleaved forest without conifers and with a relatively low portion of steppe plants.

In the material filling other tunnels (1,2, and 4), the contents of all microbiomorphs components turned were insignificant. Obviously, in this case, as in the case of the study of the material of filling of the mole rat tunnel in the background forest soil, this humified material was from the lower part of the humus horizon, in which the content of phytoliths is very low.

Data on the radiocarbon ages of humus in the background forest soil and in the buried dark gray forest soils (Fig. 6) (including the humified material of mole rat tunnels) (pit 10) together with data on the phytolith complexes of these soils have been used to reconstruct the environmental history of this area. 

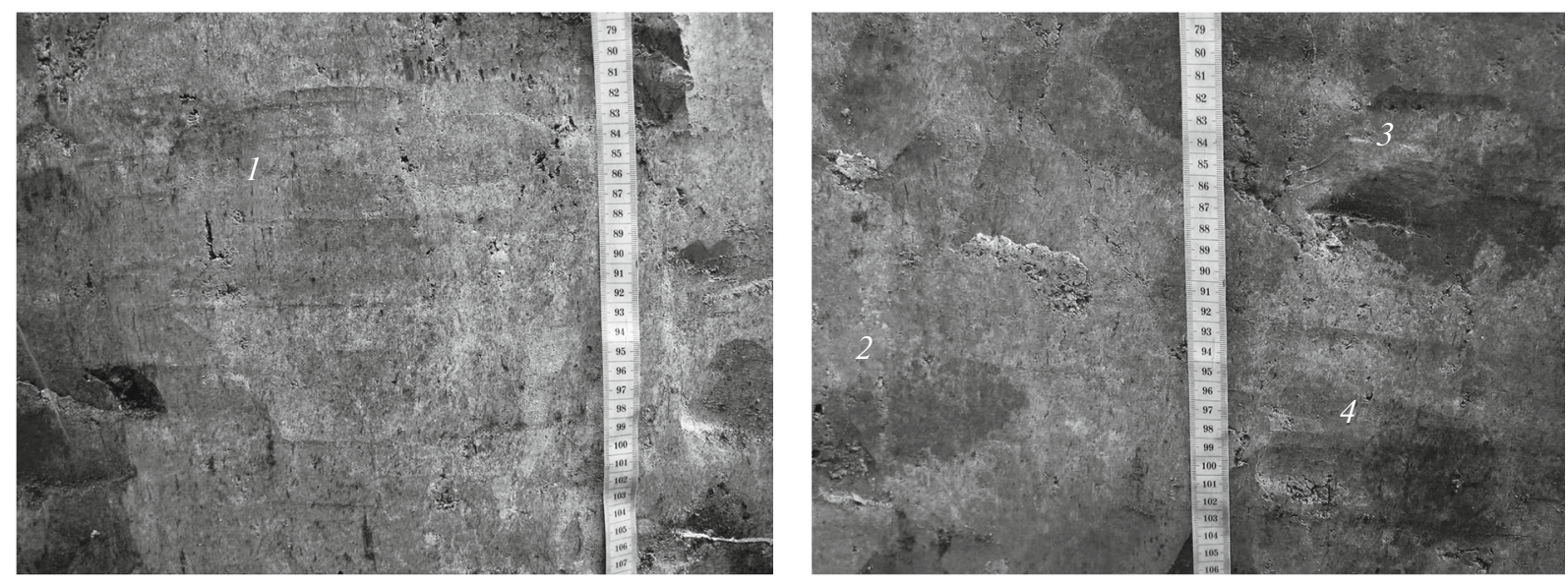

Fig. 5. Paleotunnels of mole rats left in the buried soil at the bottom of the paleohollow; their depths correspond to those presented in Table 1: (1) 85-98, (2) 95-105, (3) 80-90, and (4) $100-110 \mathrm{~cm}$.

Figure 7 shows changes in the amount of phytoliths down the soil profiles examined in pits 3 and 10 . The number of phytoliths rapidly decreases with depth and is close to zero at the depth of about $40 \mathrm{~cm}$. The identified distribution pattern is close to that established earlier on a large number of other objects, including gray forest soils [7].

The absolute age of humus in the mole rat tunnel of pit 10 (in the sample that contained phytoliths, 80$90 \mathrm{~cm}$ from the surface of the buried soil) is $6680 \pm$ $120 \mathrm{BP}$ (Ki-19383). The number of phytoliths found in the visual field of the microscope in this sample is 21 . Judging distribution curves of the number of phytoliths at different depths, this may correspond to the



Fig. 6. Changes in the radiocarbon age of soil humus in the area of Sorokino 1 archeological site (the dates were obtained for 2-cm-thick soil layers at different depths): (1) background dark gray forest soil, pit 3; (2) buried dark gray forest soil, pit 10 . Noncalibrated dates are presented. depth of $35 \mathrm{~cm}$ from the soil surface. The materials filling this tunnel could be derived from the soil horizon at the depth of $30-40 \mathrm{~cm}$.

According to plots of the distribution of radiocarbon ages of soil organic matter in the soil profiles, the layer of 30-40 cm of the modern soil has the age of $1500 \pm 200$ BP. Taking into account the radiocarbon age of humus in the filling of the studied paleotunnel, the reconstructed time of its formation and filling with the humified material is $6680-1500=5380 \mathrm{BP}$. As the material of the filling initially was at some depth $(30-40 \mathrm{~cm})$ from the surface, its real age may be several centuries older.

The most likely range of variation in the thickness of the humus part of the soil profiles, from which the material penetrated the tunnels of mole rats, was about $40-60 \mathrm{~cm}$. This assumption is based on the morphometric parameters of the studied soils: the humified part of the profiles of the background and buried dark gray forest soils extends to the depth of $40-50 \mathrm{~cm}$; in the chernozems on the valley slopes, it could be about $50-60 \mathrm{~cm}$.

As the filling of other paleotunnels did not contain phytoliths, it is highly likely that they were filled with material taken from the deep $(>40 \mathrm{~cm})$ soil horizons, but no deeper than the lower boundary of the humus layer (because this material is of gray color and contains considerable amount of humus). Thus, the most probable zone of formation of the paleotunnels by mole rats in the ancient soils was about $40-60 \mathrm{~cm}$. The radiocarbon age of humus in this layer of the modern soil corresponds to the interval of 1700-2600 BP. Having information about the age of humus in the paleotunnels and subtracting it from the extreme dates of this interval, we can estimate the time of the burrowing activity of mole rats.

Thus, the paleotunnel in the background soil (pit 3) has the humus age of $10900 \pm 150 \mathrm{BP}$ (Ki-19389); it could be formed 8300-9200 BP. The paleotunnel with 
the humus age of $4220 \pm 160 \mathrm{BP}(\mathrm{Ki}-19388)$ could be formed in the interval 1600-2500 BP. The first, more ancient time interval fits the idea of the forest-steppe nature of the vegetation and soils in the studied area in the Early Holocene (taking into account the known information $[9,12])$. The second time interval could be due to the appearance of steppe vegetation during the first stage of the development of this territory in the Early Iron Age. It is also possible that the development of steppe vegetation in the form of "islands" among broadleaved forests took place in the Scythian-Sarmatian period of climatic aridization noted by several authors $[1,15]$.

In the buried soil (pit 10), the reconstructed periods of the formation of paleotunnels are as follows: for the filling with the humus age of $7700 \pm 180 \mathrm{BP}(\mathrm{Ki}-19382)$, 5100-6000 BP; for the filling with the humus age of $7460 \pm 180 \mathrm{BP}$ (Ki-19381), 4900-5800 BP; and for the filling with the humus age of $7260 \pm 150 \mathrm{BP}(\mathrm{Ki}-19384)$, 4700-5600 BP. All these ranges are within the intervals of 4700-6000 BP (for humus) and 5100-5600 BP (for paleotunnels), which corresponds to the end of the Atlantic period of the Holocene. At about the same time, other authors noted the development of steppe vegetation in the northern half of the Central Russian Upland [9], including the territory of the Kulikovo Field [14].

Returning to the studied phytolith complex of the mole rat tunnel in pit 3, its age is about $5400 \mathrm{BP}$. As the material filling the tunnel was initially found at some depth $(30-40 \mathrm{~cm})$ from the surface, we can suppose that the composition of phytoliths in it characterized vegetation of an earlier period, i.e., of the end of the Holocene climatic optimum (>6000 BP), when broadleaved forests were widely developed on the watersheds under conditions of a warm and wet climate; in some places, they occupied interfluves of the modern meadow-steppe landscapes of the foreststeppe zone [18].

The study of the soil on the territory of the ancient Russian settlement of Sorokino 1 will be incomplete without considering another aspect, namely, data on the bulk density of the soils buried in the bottom of the paleohollow under new portions of sediments in the 13th century AD. These data are presented in Fig. 8.

In the central (bottom) part of the paleohollow, the zone of increased soil compaction is revealed; we suppose, it appeared in the place of regular passes of the inhabitants of the ancient Russian settlement along the trail. Given the closeness of the river, toward which the lower end of the paleohollow opens, this assumption seems quite plausible. The width of the path, reconstructed in the compaction zone, was about $4 \mathrm{~m}$, with the central part (about $2 \mathrm{~m}$ ) being the most dense. The phytolithic complex of the upper layer of $0-5 \mathrm{~cm}$ of the soil in the bottom of the paleohollow contains allochthonous material (reed, cereal crops), which could get there on the shoes of the residents. of the

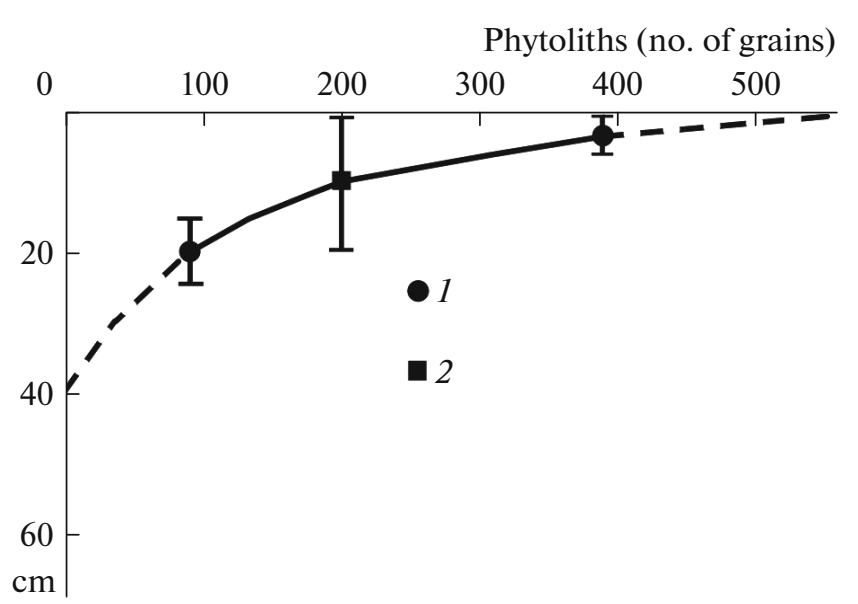

Fig. 7. Changes in the number of phytoliths (per visual field of the microscope according to [7]) at different depths in the (1) buried dark gray forest soil (pit 10) and (2) background dark gray forest soil (pit 3 ). m.

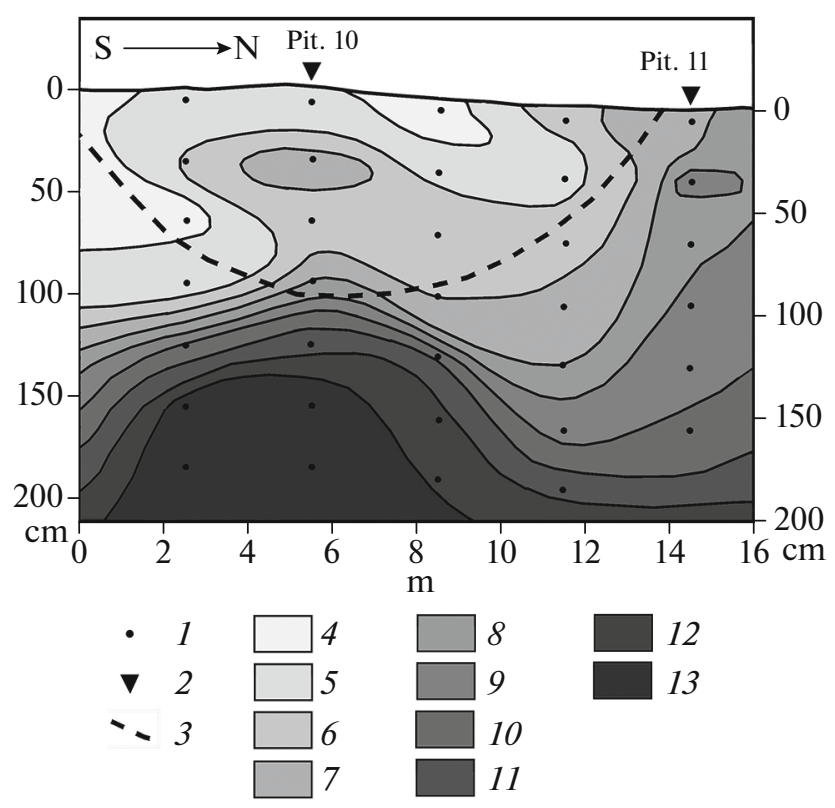

Fig. 8. Distribution of bulk density values in the soils of the paleohollow within the Sorokino 1 archeological site (northeastern part of the excavation): (1) sampling loci, (2) soil profiles examined in pits 10 and 11, and (3) bottom and slopes of the paleohollow; (4-13) bulk density grades $\left(\mathrm{g} / \mathrm{cm}^{3}\right)$ : (4) $\leq 0.8$, (5) $0.81-0.9$, (6) $0.91-1.0$, (7) 1.01-1.1, (8) $1.11-1.2$, (9) $1.21-1.3$, (10) $1.31-1.4$, (11) $1.41-1.5$, (12) $1.51-1.6,(13)>1.6$.

settlement). The soil overcompaction by humans could result in the increase of the radiocarbon age of humus, which in the upper horizon of this soil is 3500 years older than in the analogous soil beyond the trail (Fig. 6), although the real difference (1950 1240 ) is about 700 years.

We suppose that the trampling of natural vegetation and soils in the bottom and on the slopes of the 
paleohollow was one of the main factors for the development of erosional processes, which eventually led to the burial of the paleohollow under a layer of humified fine earth with pottery fragments dating back to $1200-$ 1240 AD. Otherwise (without disturbing the vegetation cover), erosion would not have developed, as was found for slope surfaces even of significant steepness under natural cover with forest or steppe vegetation [6].

During the period when the bottom of the hollow was filled with eroded sediments, the trail continued to function, which was reflected in the increased density of soil layers in the material covering the buried soil, directly above the areas of the earlier compaction.

\section{CONCLUSIONS}

The study of paleosol indicators of the state of the environment in the old Russian settlement of Sorokino 1 and in its vicinity attests to considerable changes in vegetation and soils during the Holocene under the impact of natural and anthropogenic factors.

The climate-driven alternation of the phases with steppe and forest vegetation took place. In the Boreal period, steppe vegetation predominated. During the Holocene climatic optimum (the Middle Atlantic period), steppes were replaced by broadleaved forests. At the end of the Atlantic period, the next phase of steppe propagation took place. It was marked by the activation of the burrowing activity of steppe mole rats. Steppes also expanded during the Little Climatic optimum and were later replaced by forests during the Little Ice Age. Judging the character of phytolith complexes of different ages, forests in the Late Holocene corresponded to colder conditions than forests in the Middle Holocene and consisted of mixed coniferous and broadleaved tree species.

During the period of the existence of the ancient Russian settlement, the environment was subjected to various anthropogenic influences. Findings of phytoliths of cultivated cereals indicate the existence of arable land near the settlement. According to the features of compaction of the soil in the bottom of the hollow crossing the ancient settlement and open to the river, there was a trail to the river floodplain along the bottom of the hollow. Constant trampling of vegetation on the trail and adjacent slopes could lead to the erosion of the slope and burying of the soil in the bottom of the hollow under the layer of humified loam during the period of functioning of the settlement.

In the modern period of the economic development of this territory in the past three centuries, forests were partially replaced by agricultural land (cropland, hayfields, pastures). Deforestation and use of the soils as croplands and hayfields for more than 230 years have led to the appearance of chernozemic features in the former gray forest soils. On the watershed slopes under arable land, dark gray forest soils have been transformed into podzolized chernozem; podzolized chernozems on the slope of the river valley have been transformed into leached chernozem under the impact of meadow-steppe vegetation of the regularly mown hayfields.

These results prove the great informational value of interdisciplinary soil-archeological investigations.

\section{FUNDING}

This study was supported by the Russian Science Foundation, project no. 14-17-00171; phytolith analyses were performed in agreement with state contract no. 0148-2019-0006.

\section{REFERENCES}

1. A. L. Aleksandrovskii and E. I. Aleksandrovskaya, Soil Evolution and the Environment (Nauka, Moscow, 2005) [in Russian].

2. A. L. Aleksandrovskii and A. A. Golyeva, "Paleoecology of ancient man according to the data of interdisciplinary studies of soils of archeological sites in the Upper Don region," in Archeological Monuments of the Forest-Steppe Don Region (Lipetsk, 1996), No. 1, pp. 176-183.

3. A. L. Aleksandrovskii, E. G. Ershova, N. A. Krenke, N. O. Kovaleva, E. V. Ponomarenko, and O. I. Tyutereva, "Soil evolution in the Moskva River Valley in the Late Glaciation and Holocene," in Proceedings of VII Congress of the Dokuchaev Soil Science Society of Soil Scientists and All-Russian Scientific Conference with International Participation "Achievements of Soil Science in Food and Ecological National Safety" (Moscow, 2016), Part 2, pp. 170-171.

4. K. T. Budanova, "Geomorphology. Landscapes," in Atlas of Orel Oblast, Ed. by A. P. Sharapenko (Russian Federal Service of Geodesy and Cartography, Moscow, 2000), p. 9.

5. Three Versts in Length Military Topographic Map, Scale 1: 126000 of Orel and Kaluga Provinces (Military Topographical Administration, St. Petersburg, 1867), Row 16, Sheet 13.

6. V. N. Golosov, A. N. Gennadiev, K. R. Olson, M. V. Markelov, A. P. Zhidkin, Yu. G. Chendev, and R. G. Kovach, "Spatial and temporal features of soil erosion in the forest-steppe zone of the East-European Plain," Eurasian Soil Sci. 44, 794-801 (2011).

7. A. A. Golyeva. Microbiomorphic Complexes of Natural and Anthropogenic Landscapes: Genesis, Geography, and Information Role (LKI, Moscow, 2008) [in Russian].

8. L. E. Gorokhov and G. V. Koveshnikov, "Quaternary deposits," in Atlas of Orel Oblast, Ed. by A. P. Sharapenko (Russian Federal Service of Geodesy and Cartography, Moscow, 2000), p. 12.

9. V. A. Klimanov and T. A. Serebryannaya, "Dynamics of vegetation and climate of the Central Russian Upland in the Holocene," Izv. Akad. Nauk SSSR, Ser. Geogr., No. 2, 26-37 (1986).

10. M. A. Olenichev and L. P. Stepanova, "Soils," in Atlas of Orel Oblast, Ed. by A. P. Sharapenko (Russian Federal Service of Geodesy and Cartography, Moscow, 2000), p. 19. 
11. Orel Region Ruled by Governor General, Bolkhovskii Uezd, General Plan of Bolkhov Town Plan and Its Uezd Included in Orel Region, Written in Kursk Region Ruled by Governor General in Land Office in 1785, Russian State Archive of Ancient Documents (RGADA), Fund 1356, Inventory 1 , File 8 .

12. T. A. Serebryannaya, "Dynamics of the boundaries of central forest-steppe in the Holocene," Conference in Memoriam of Academician V.N. Sukachev "Century Dynamics of Biogeocenosises” (Nauka, Moscow, 1992), pp. 54-71.

13. M. N. Tikhomirov, Russia in the 16th Century (Academy of Sciences of USSR, Moscow, 1962) [in Russian].

14. N. A. Khotinskii, "Anthropogenic transformation of landscapes of Kulikovo Field: protection and recovery," in Anthropogenic Evolution of Geosystems and Their Components (Moscow, 1987), pp. 69-87.

15. Yu. G. Chendev, Evolution of Forest-Steppe Soils of the Central Russian Upland in the Holocene (GEOS, Moscow, 2008) [in Russian].

16. Yu. G. Chendev, "Response of gray forest soils to agricultural development under different climatic conditions," Izv. Akad. Nauk SSSR, Ser. Geogr., No. 2, 8795 (2012).

17. Yu. G. Chendev, A. L. Aleksandrovskii, O. S. Khokhlova, L. G. Smirnova, L. L. Novykh, and A. V. Dolgikh, "Anthropogenic evolution of dark gray forest-steppe soils in the southern part of the Central Russian Upland," Eurasian Soil Sci. 44, 1-12 (2011).
18. Yu. G. Chendev, E. G. Ershova, A. L. Aleksandrovskii, E. V. Ponomarenko, A. A. Golyeva, O. S. Khokhlova, A. V. Rusakov, and A. S. Shapovalov, "Soil and botanical notes on dynamics of the environment in Yamskaya steppe in the Holocene," Izv. Akad. Nauk SSSR, Ser. Geogr., No. 2, 75-89 (2016).

19. C. Bronk Ramsey and S. Lee, "Recent and planned developments of the program OxCal," Radiocarbon 55 (2-3), 720-730 (2013).

20. IUSS Working Group WRB, World Reference Base for Soil Resources 2014, International Soil Classification System for Naming Soils and Creating Legends for Soil Maps, World Soil Resources Reports No. 106 (Food and Agriculture Organization, Rome, 2014).

21. P. J. Reimer, E. Bard, A. Bayliss, J. W. Beck, P. G. Blackwell, C. Bronk Ramsey, P. M. Grootes, T. P. Guilderson, H. Haflidason, I. Hajdas, C. Hatt, T. J. Heaton, D. L. Hoffmann, A. G. Hogg, K. A. Hughen, et al., "IntCal13 and Marine 13 radiocarbon age calibration curves $0-50,000$ years cal BP," Radiocarbon 55 (4), 1869-1887 (2013).

22. V. Skripkin and N. Kovalyukh, "Recent developments in the procedures used at the SSCER laboratory for the preparation of lithium carbide," Radiocarbon 40 (1), 211-214 (1998).

Translated by D. Konyushkov 